\title{
The Specifics of Functioning of Higher Education System of Culture and Art in Russian Regions
}

\author{
Nataliya Anatolevna Malshina, ${ }^{1, *}$
}

\begin{abstract}
${ }^{1}$ The Department of Humanitarian Disciplines, Saratov State Conservatoire named after L. V. Sobinov, Saratov, Russia *Corresponding author. Email: malsnataliya@yandex.ru
\end{abstract}

\begin{abstract}
From our point of view, it seems advisable to introduce a new criterion - an integral potential of sociocultural sphere that consists of interconnected indicators: economic, social, cultural, technological, resource, innovative. The analysis shows that over the research period the quantitative indicators of functioning of higher education system of culture and art did not change and the expenditure of consolidated budgets of RF regions on socio-cultural events, on education (millions of rubles) increase at the regional scale. Far Eastern Federal District, Siberian Federal District, Volga Federal District belong to the regions with the highest growth percentage of expenditure. The structure of the financial and economic activity of the education system of culture and art includes the major indicators: the revenue of a higher educational institute from all sources (thousands of rubles), the revenue from nongovernment sources (thousands of rubles) $(\%)$, the fraction of the revenue of a higher educational institution from non-governmental sources $\%$, the fracture of the revenue of a higher educational institution from federal budget $\%$, the fracture of the revenue of a higher educational institution from the budget of a constituent entity of the Russian Federation and local budget \%, the fracture of the revenue of a higher educational institution from educational activity in total revenue of a higher educational institution \%, the fracture of the revenue of a higher educational institution from research and development activities in total revenue of a higher educational institution \%, the fracture of extra budgetary means in the revenue from educational activity \%, the fracture of extra budgetary means in the revenue from research and development activities. The most important factors in the development and assessment of the potential of higher education in culture and art include scientific research, salary, financial and economic activity, etc. It is proposed a methodological approach to the analysis of the functioning of higher education system of culture and art. Its distinctive feature is the determining and maintaining the eligibility between the level of regional education of culture and art and the value of expenditure of consolidated budgets what in turn leads to an improvement of the strategic and competitive positions of the region in conditions of system relevance of the economy.
\end{abstract}

Keywords: higher education of culture and art, the cultural industry, Russian regions

\section{INTRODUCTION}

In many countries, the sphere of social and cultural services has shown their high economic, investment and social effectiveness. The system of higher education in the field of culture and art is considered as one of the components of socio-cultural potential. The system of higher education of culture and art forms the cultural and intellectual potential and as a result, human capital of Russia. The strategic directions for cultural potential development of Russia include the development of

*The study was conducted with financial support from the Russian Federal Property Fund, project № 19-010-01004 "The Development of Organizational, Economic and Financial Mechanisms for Support and Strategic Development of the Cultural Industry in Russian Regions" science, technology, the training of qualified personnel in the field of socio-cultural technologies, the formation of modern cultural and information infrastructure, provision of high-quality services and providing high level of accessibility of information and technologies in the cultural sphere for population.

All considered components exist in a single continuous connection and are integrated into the regional socio-cultural processes of society. The integral potential of socio-cultural sphere becomes the basis for the formation of a regional services market due to the natural factors and infrastructure of the region [1].

According to the presented modern socio-cultural situation, the main goal of the research is to analyze the 
specifics of the functioning of the higher education system of culture and art in Russian regions. The main objectives of the research are as follows: to study the sources and the structure of financing the educational system of culture and art; to identify the most important factors in the development and assessment of the potential of higher education in culture and art; to form recommendations, key indicators of evaluation the functioning of the higher education system of culture and art.

\section{THEORETICAL BASE OF THE RESEARCH}

The socio-cultural sphere includes various types and spheres of social activities for the development of human potential as the source and ultimate goal of social development. The socio-cultural sphere is a set of enterprises, institutions, organizations and administrating authorities that produce, distribute, preserve and organize the consumption of goods and services for socio-cultural and information purposes, providing the satisfaction of cultural and information needs of residents. This sphere represents the joint socio-cultural organization of society and includes the following groups or branches:

- education and professional training;

- science and science services;

- health and social security;

- housing, communal and domestic services;

- culture, art and mass media;

- physical education and sport;

- tourism and hospitality industry and recreation services [2].

At first, it is necessary to define and specify the conceptual apparatus of the sphere under study. From an economic point of view, "potential" is defined as the maximum possible result of a particular level of management that can be achieved using the full range of available resources. The potential is an integrated specification of available resources at a specific place and time [3]. The potential is complex of all available capabilities and means in a sphere that can be used to solve a problem, achieve a certain goal. The potential is a complex, multifactorial, multivariable phenomenon the study of which is originally difficult because there is no common definition of this concept and the system of indicators for its evaluation adapted for the cultural sphere is not fully developed.

In the context of this research, the cultural potential of socio-cultural sphere should be defined as the combination of accumulated resources of culture, means, sources, reserves and opportunities. On the one hand, they are accumulated by society in the form of material and spiritual results of human labor, and on the other hand, they are presented as cultural values and cultural heritage objects. From the narrow perspective, cultural potential is a combination of objective and subjective opportunities or factors that facilitate the development of the cultural space of a city or a region.

"Materialized" culture potential is manifested in the possession of specific objects of cultural value. Thus, only "institutional" and "materialized" potentials can be evaluated. "Assimilated" cultural potential is not quantifiable and expressed in qualitative indicators. In this research, the quality is considered as the degree of utility of consuming capacity of services that is degree of conformity to the need, the suitability to meet the need under specific economic conditions.

The analysis of the conceptual apparatus of the service system reveals its existent imperfections that can be eliminated on condition of additional theoretical analysis and legal response. The appliance of the concepts interpretation proposed by the author will contribute to the further development of the categorical apparatus of the service system that can facilitate the formation of the legislative framework of the state development policy of Russia for the long term.

\section{METHODS OF THE RESEARCH}

The realization of the goals and objectives set in the research can be fully implemented only on the basis of a thorough comprehensive analysis of modern researches on the problems of theory, methodology and practice of education, the market for cultural services, resource management, both Russian and foreign authors. At present time there has been observed an increasing interest in cultural research that allows for the regulation, improvement and sustainable development of its research methodology.

As the general methodological basis of the research are used the methods of dialectics and the systematic approach of analysis including the works of Russian and foreign scientists on the problems of potential assessment of the socio-cultural sphere and increasing the effectiveness of functioning mechanisms. The methodological basis of the research are methodological provisions presented in scientific publications, legislative and regulatory acts, methods of systematic, techno-economic and financial analysis, methods of statistical groups and comparative analysis.

The analysis undertaken in the work is based on the unity of logical and historical approaches, the principle of cause-and-effect relations and reverse causality. The work used statistical and calculation research instruments. The objectives are based on institutional, economic and statistical analysis; time-series analysis; comparative and system analysis; correlation and regression analysis; organizational and economic 
modelling. During the study, general scientific methods of cognition will be used: abstraction, analysis, systematization, structuring.

For obtaining a true picture during the comprehensive research practice to assess the development and effectiveness of the higher education system of culture and art, basic methods of data collection were used including monitoring of certain indicators of the cultural sphere development, analysis of statistics from Federal Service of State Statistics and Culture Ministry of the Russian Federation.

\section{THE INTEGRAL POTENTIAL OF SOCIO- CULTURAL SPHERE}

According to various estimates, the "overproduction" of higher education professionals exceeds quantitative needs of labor market by half but meets the qualitative need by only $83 \%$. As a result, many university graduates perform work that does not require such level of professional training or they are non-competitive in the labor market and without employment what confirms the negative impact of this process on the structure, quality and development of human capital. The actual goal of higher education is not acquiring of special professional knowledge but obtaining of a formal title and social status in order to have a high standard of wages in the future. At the same time, labor demand is supplied by the system of primary and secondary vocational education quantitatively by $85-86 \%$, qualitatively (taking into account the level of qualification) by $43 \%$ and for middle-level specialists - by $60 \%$ [4]. There is certain vacuum in the ratio of qualitative need and quantitative demand for highly qualified professionals. Since the higher system education of culture and art affects the formation of intellectual and cultural potentials, it seems especially important to analyze the functioning of this sphere in regions.

One of the most important tasks in modern economic science is to determine the potential of sociocultural sphere. It is clear that there are unimproved opportunities for the development of this sphere. Further study and potential assessment of socio-cultural sphere in Russia is impossible without taking into account regional specific features since each territorial subject of the Russian Federation has different conditions for economic, social and cultural development. The major sources for primary acquisition are accepted report forms. From our point of view, it seems advisable to introduce a new criterion an integral potential of socio-cultural sphere that consists of interconnected indicators: economic, social, cultural, technological, resource, innovative. This enables to assess unimproved sources of competitive recovery at the investigated area objectively and fully. In addition, it will take into account multiplicative effect of accomplishment of potential that is the increasing of primary employment directly in this fraction of service industry market as well as expansion of employment in interconnected industries, cost reduction of searching and hiring of qualified professionals.

It is proposed to use management methodology based on the synthesis of approaches. The holistic and comprehensive approaches determine the need to take into account all factors and their dynamics; the synergetic one provides the integration of components that form the comprehensive (integrated) potential of socio-cultural sphere. The approach to the establishment of comprehensive potential can be expressed by the following formula [5]:

$$
\mathrm{CP}=\mathrm{f}\{\text { Isoc; Innp; Ekp; Етех; РRp; Рк }\}, \text { (1) }
$$

where Isoc - the social potential; Innp - the innovative potential; Ekp — the economic potential; Етех — the technological potential; PRp — the resource (infrastructure) potential; РК - the cultural potential.

Each potential requires assessment (calculation and measurement) and in the future - a specific decision for each subject.

\section{THE SPECIFITY OF THE FUNCTIONING OF HIGHER EDUCATION OF CULTURE AND ART}

According to the Effect Monitoring of Higher Education Organizations of the Russian Federation [6], the characteristics of the higher education system in the Russian Federation includes 1264 organizations of higher education including 555 branches, 10 federal universities, 29 national research universities, 21 project 5-100 participants, 920 state and municipal and 344 private organizations. There are the following groups of educational organizations of higher education with the areas of specialization:

- military and security;

- medical science;

- agriculture;

- art;

- sport;

- transport

Among them, 4,174,944 students who undertake higher education programs, including 2,397,227 students of full-time training, 1,941,901 students at the expense of budgetary means of the Russian Federation, $91.3 \%$ of students of state and municipal organizations, $8.7 \%$ students of private organizations. According to the areas of specialization: 
- mathematical and natural sciences - $5.98 \%$, $155,326.95$ students,

- engineering, technology and technical sciences $31.94 \%, 829,849.7$ students,

- health care and medical sciences - $10.89 \%$, $282,859.1$ students,

- agriculture and agricultural sciences - $3.99 \%$, $103,628.55$ students,

- $\quad$ social science $-30.25 \%, 786,077.7$ students,

- education and pedagogical sciences $-8.96 \%$, $232,801.3$ students,

- the humanities $-5.00 \%, 129,957.9$ students,

- art and culture $-2.99 \%,-77,791.6$ students,
- national defense and security, military sciences $-0,00 \% ., 33$.

The total number of monitoring participants includes eight federal districts with their regions except organizations of federal public authorities that provide the training of personnel to the benefit of national defense and security, law enforcement as well as organizations that did not provide information within the framework of the monitoring.

All records of organization of higher education system analyze the effectiveness of functioning in reliance on major groups of indicators for each year according to the spheres of activity of higher education institutes. For these reasons, the indicators are brought into a summary table. ("Table I")

TABLE I. THE SUMMARY TABLE OF INDICATORS ON THE SPHERES OF ACTIVITY OF THE SUBJECT OF HIGHER EDUCATION SYSTEM OF CULTURE AND ART IN THE DYNAMICS

\begin{tabular}{|l|l|l|l|l|l|l|l|l|}
\hline \multirow{2}{*}{ № Indicator } & \multicolumn{5}{c|}{ The Indicator Value of Higher Education Institute over the Years } \\
\cline { 3 - 8 } & & 2012 & 2013 & 2014 & 2015 & 2016 & 2017 \\
\hline $\boldsymbol{E . 1}$ & Educational Activity & 83.23 & 87.61 & 85.37 & 89.43 & 87.49 & 91.71 & 87.97 \\
\hline $\boldsymbol{E . 2}$ & Scientific Research & 77.84 & 132.29 & 178.22 & 161.05 & 174.53 & 262.39 & 246.82 \\
\hline $\boldsymbol{E . 3}$ & International Activity & 13.4 & 12.12 & 12.94 & 14.74 & 15.84 & 16.93 & 16.87 \\
\hline $\boldsymbol{E . 4}$ & Financial and Economic Activities & 1243.7 & 1171.96 & 1276.8 & 1398.85 & 1705.85 & 1935.6 & 1654.5 \\
\hline $\boldsymbol{E . 5}$ & Salary of Teaching Staff & - & - & 160.61 & 179.28 & 190.85 & 196.68 & 215.2 \\
\hline $\boldsymbol{E . 6}$ & Employment & 100 & 99.115 & 90 & - & 90 & 85 \\
\hline $\boldsymbol{E . 7}$ & The Additional Indicator & 0.67 & 66.26 & 58.59 & 72.51 & 67.76 & 76.47 & 76.97 \\
\hline $\boldsymbol{E . 8}$ & Infrastructure & 9.23 & 9.41 & - & - & - & - \\
\hline
\end{tabular}

The tables of the Major Information Computing Centre archives show the following spheres of activity: educational activity, scientific research, international activity, financial and economic activities, infrastructure, employment, salary of teaching staff, and the additional indicator. It should be noted that infrastructure indicators are presented only for 2012 and 2013, salary indicators are presented since 2014, and the employment indicators are not presented in 2015 and 2018.

The indicator "Educational Activity" shows heterogeneous dynamics: minimum was achieved in 2014 (85.37), maximum - in 2017 (91.71), the increment is 6.34 unities. In general, the growth dynamics sustains, the increment over the period under review is 4.74 unities $-6 \%$.

The indicator "Scientific Research" shows strong growth, except 2015 with the lowest value, and then the numbers grow and reach their maximum in 2017. By the end of the period, the value of the indicator is again slightly declining. Over the period under review the increment is 168.98 unities $-217 \%$.

The indicator "International Activity" is characterized by fluctuation in values and their slight growth. From the beginning to the end of the period the increment is 3.47 unities - 26\%. The indicator "Financial and Economic Activities" shows heterogeneous dynamics: minor recession in 2013 is replaced by a constant increase and it reaches its maximum by 2017, then there is a significant recession. The increment for the entire period is 410.8 unities $33 \%$.

The indicator "Salary of Teaching Staff" is characterized by a constant increase in values by an average of $7.25 \%$. The maximum in 2015 is $11 \%$ from the value of 2014, the minimum in 2017 is $3 \%$ from the value of 2016. From the beginning to the end of the period the increment is 54.59 unities - 33\%.

The indicator "Employment" is characterized by a steady decline in values and their lack in 2015 and 2018. The maximum value at the beginning of the period decreases by $15 \%$ by the end of the period.

The additional indicator is described in more detail on the website and includes many different criteria. During the analysis it is characterized by fluctuations of values: at the beginning of the period there is a fast growth 2010 - 2015, then the values stabilize with minor deviations in one direction or another and reach their maximum by the end of the period in 2018. The increment is 76.3 unities $-11288 \%$. 
The indicator "Infrastructure" is presented in the table in 2012 and 2013. Its value is characterized by slight growth of 0.18 unities that is $1.9 \%$.

Thus, it can be concluded that there is an increase in values in the indicators of all spheres of activity of the higher education institution of culture and art except the indicator E.6 "Employment" that shows a decrease (since 2012, the value of the indicator was 100, in 2017 it is decreased to 85 , that is $15 \%$ ). The minimum increase of values is observed in the indicator E.1 "Educational Activity" (the increment is 4.74 unities $6 \%$ ), the maximum is in the indicator E. 8 "The
Additional Indicator" (the increment is 76.3 unities $112 \%)$.

\section{THE SYSTEM OF HIGHER EDUCATION OF CULTURE AND ART IN REGIONS}

For identifying the macroeconomic situation of the higher education system of culture and art in regions it seems necessary to analyze the correlation with the expenditure of consolidated budgets of RF regions for socio-cultural events from them for education (millions of rubles) drawn from the official public sources [7] ("Table II").

TABLE II. THE SYSTEM OF HIGHER EDUCATION OF CULTURE AND ART IN REGIONS $2018-17$.

\begin{tabular}{|c|c|c|c|c|c|c|c|c|}
\hline & \multicolumn{4}{|c|}{2018} & \multicolumn{4}{|c|}{2017} \\
\hline The Regions & $\begin{array}{l}\text { The Number of } \\
\text { Educational } \\
\text { Organizations of } \\
\text { Art and Culture } \\
\end{array}$ & $\%$ & $\begin{array}{l}\text { Student } \\
\text { Body }\end{array}$ & $\begin{array}{l}\text { Total } \\
\text { Expenditure } \\
\text { in the Region }\end{array}$ & \begin{tabular}{|ll} 
The Number & of \\
Educational & \\
Organizations & of \\
Culture and Art & \\
\end{tabular} & & Student Body & $\begin{array}{l}\text { Total Expenditure } \\
\text { in the Region }\end{array}$ \\
\hline $\begin{array}{ll}\text { Central } & \text { Federal } \\
\text { District } & \end{array}$ & 39 & 3.79 & 31326.9 & 766729.7 & 39 & 3.79 & 31326.9 & 730626.2 \\
\hline $\begin{array}{l}\text { Northwestern Federal } \\
\text { District }\end{array}$ & 9 & 5.28 & 15831.5 & 345416.4 & 9 & 5.28 & 15831.5 & 298822.8 \\
\hline Volga Federal District & 12 & 1.76 & 8731.05 & 491722.4 & 12 & 1.76 & 8731.05 & 384977.4 \\
\hline $\begin{array}{|ll|}\begin{array}{l}\text { Southern } \\
\text { District }\end{array} & \text { Federal } \\
\end{array}$ & 8 & 2.65 & 6514.8 & 243194.9 & 8 & 2.65 & 6514.8 & 221183.6 \\
\hline \begin{tabular}{|l|l|} 
North Caucasian \\
Federal District \\
\end{tabular} & 1 & 0.95 & 1128.1 & 103179 & 1 & 0.95 & 1128.1 & 129036.6 \\
\hline Urals Federal District & 7 & 3.4 & 5444.9 & 336347.5 & 7 & 3.4 & 5444.9 & 287781.3 \\
\hline $\begin{array}{|ll|}\begin{array}{l}\text { Siberian } \\
\text { District }\end{array} & \text { Federal } \\
\end{array}$ & 8 & 1.89 & 5871.3 & 259162.9 & 8 & 1.89 & 5871.3 & 168484.4 \\
\hline $\begin{array}{l}\text { Far Eastern Federal } \\
\text { District }\end{array}$ & & 2.46 & 2943.05 & 220501.9 & 5 & 2.46 & 2943.05 & 121249.9 \\
\hline
\end{tabular}

The analysis shows that over the research period the quantitative indicators of functioning of higher education system of culture and art did not change and the expenditure of consolidated budgets of RF regions on socio-cultural events, on education (millions of rubles) increase at the regional scale. Far Eastern Federal District, Siberian Federal District, Volga Federal District belong to the regions with the highest growth percentage of expenditure.

\section{CONCLUSION}

The system of education of culture and art is a new aspect of economic development and certainly requires in-depth study, development and planning. The place of education in the system of formation of cultural and intellectual potential has not been sufficiently studied what could reveal insights into regional specific features of reprocessing of human capital through the system of vocational education in culture and art. The contribution of the educational system to economic growth is that it serves as a kind of "device" whereby employers can undertake the highly skilled professionals' selection [8].
From the perspective of the application sphere, in the structure of human capital the higher education system of culture and art forms humanitarian human capital that is the capital used in the field of creating new human capital (education, artistic activities, etc.).

The structure of the financial and economic activity of the education system of culture and art includes the major indicators: the revenue of a higher educational institute from all sources (thousands of rubles), the revenue from non-government sources (thousands of rubles) $(\%)$, the fraction of the revenue of a higher educational institution from non-governmental sources $\%$, the fracture of the revenue of a higher educational institution from federal budget $\%$, the fracture of the revenue of a higher educational institution from the budget of a constituent entity of the Russian Federation and local budget $\%$, the fracture of the revenue of a higher educational institution from educational activity in total revenue of a higher educational institution \%, the fracture of the revenue of a higher educational institution from research and development activities in total revenue of a higher educational institution $\%$, the fracture of extra budgetary funds in the revenue from educational activity $\%$, the fracture of extra budgetary 
means in the revenue from research and development activities.

The most important factors in the development and assessment of the potential of higher education in culture and art include scientific research, salary, financial and economic activity, etc.

In human capital one of the components is that the education enhances the allocative efficiency of production and consumption, activates technical advance improves living standards of residents, fosters the development of infrastructure. According to the theory of human capital, labor market is able constantly to absorb employees with an increasing level of education and qualification upon condition that the additional expenses involved in education can be reduced. These self-correcting labor markets can function fail-safe maintaining demand for welleducated creative community on the same level as supply.

It is evident from the above that teaching support of artistic highly-skilled professionals at all stages of professional development is of great importance in the formation of the intellectual and cultural potential of the region through the education system of culture and art.

It is proposed a methodological approach to the analysis of the functioning of higher education system of culture and art. Its distinctive feature is the determining and maintaining the eligibility between the level of regional education of culture and art and the value of expenditure of consolidated budgets what in turn leads to an improvement of the strategic and competitive positions of the region in conditions of system relevance of the economy.

As a result, it is possible to conclude that the higher education system of culture and art has sufficient untapped capacity. Many economic objectives are solved by applying the strategy to this sphere. One of these objectives is to create conductive conditions for economic growth of depressed regions of the Russian Federation.

\section{References}

[1] N. A. Malshina. The culture industry of the Russian Federation - integrated service centres: regional aspect. Advances in economics, bisines and management research AEBMR, volume 39. Competitive, Sustainable and Secure Development of the Regional Economy: "Response to Global Challenges" CSSDRE 2018. pp. 272-275

[2] Federal Law 233-FZ of December 18, 2006, amending the Federal Law "On budget classification of the Russian Federation". Electronic Source http://www.rg.ru/2006/12/23/budjet-dok.html

[3] N. A. Malshina, A. A. Filonenko. Contemporary analysis of the influence of modern trends in the development of post-industrial society on the dynamics, development and structural transformation of the cultural and creativity industry. Proceedings of the 4th International Conference on Contemporary Education, Social Sciences and Humanities (ICCESSH 2019). pp.1682-1687. https://www.atlantispress.com/proceedings/iccessh-19

[4] Creative Industries Mapping Document// Department for Culture, Media and Sport, United Kingdom. URL: www.culture.gov.uk/global/publications/archive_2001/ci_mapp ng_doc_2001.htm (accessed 02.06.2020)

[5] N. A. Malshina. Economic and Managerial Problems in the Field of Culture. Advances in Social Science, Education and Humanities Research/3rd International Conference on Judicial, Administrative and Humanitarian Problems of State Structures and Economic Subjects (JAHP 2018). pp. 94-99.

[6] Monitoring of Higher Education Organizations of the Russian Federation $2019 . \quad$ URL http://indicators.miccedu.ru/monitoring/?m=vpo (accessed 02.06.2020)

[7] Federal state statistics service: management, structure, etc. The main socio-economic indicators of Russia https://gks.ru/bgd/regl/b19_14p/Main.htm

[8] N. Rozanova, A. Nazarenko. On the Marxist View of LaborCapital Relations: Modern Approach. Voprosy Economiki. 2004. № 12. pp. 131-140. 